Article

\title{
Assessing Rare Metal Availability Challenges for Solar Energy Technologies
}

\section{Leena Grandell ${ }^{1,2, *}$ and Mikael Höök ${ }^{2}$}

1 VTT Technical Research Centre of Finland, P.O. Box 1000, FI-02044 VTT, Espoo 02044, Finland

2 Global Energy Systems, Department of Earth Sciences, University of Uppsala, Villavägen 16, Uppsala 75121, Sweden; E-Mail: Mikael.hook@geo.uu.se

* Author to whom correspondence should be addressed; E-Mail: leena.grandell@vtt.fi; Tel.: +358-207-225-700; Fax: +358-207-227-604.

Academic Editor: Andrew Kusiak

Received: 2 June 2015 / Accepted: 20 August 2015 / Published: 26 August 2015

\begin{abstract}
Solar energy is commonly seen as a future energy source with significant potential. Ruthenium, gallium, indium and several other rare elements are common and vital components of many solar energy technologies, including dye-sensitized solar cells, CIGS cells and various artificial photosynthesis approaches. This study surveys solar energy technologies and their reliance on rare metals such as indium, gallium, and ruthenium. Several of these rare materials do not occur as primary ores, and are found as byproducts associated with primary base metal ores. This will have an impact on future production trends and the availability for various applications. In addition, the geological reserves of many vital metals are scarce and severely limit the potential of certain solar energy technologies. It is the conclusion of this study that certain solar energy concepts are unrealistic in terms of achieving TW scales.
\end{abstract}

Keywords: solar energy; solar cells; rare metals; material constraints

\section{Introduction}

Continued oil dependence is environmentally, economically and socially unsustainable [1]. Peaking of conventional oil production has been a topic of interest for more than 50 years [2]. Anthropogenic emissions of greenhouse gases and potentially harmful climatic change are strongly connected to future hydrocarbon combustion [3], so reducing fossil fuel use has been an integral part of climate 
negotiations. All this has resulted in renewed interest in alternative energy systems. IPCC states that the present energy system is not sustainable and that the solar energy could become a significant contributor to the energy infrastructure [4].

Solar energy is commonly seen as a future energy source with significant potential. The amount of energy that the Earth receives from the sun in a single hour is many times greater than the combined output of fossil energy. Harvesting this abundant solar influx could, in theory, supply mankind with all the energy it demands for millions of years. However, Ion concluded that the supply potential of an energy source is generally dependent on concentration [5]. Numerous inexhaustible energy sources exist, but their practical significance is often hampered by low energy density. This applies to solar energy as it arrives in dilute form (up to $2500 \mathrm{kWh} / \mathrm{m}^{2}$ annually depending on location) requiring significant area in comparison with more concentrated energy sources such as coal or nuclear.

To mitigate the low energy concentration in solar rays, numerous technical solutions have been put into practice while others are being developed. Photovoltaic solar cells of various types capable of converting the solar rays directly to electricity are already in the market, while concentrating solar power based on thermal cycles is another solution. Another possibility is artificial photosynthesis, aiming at mimicking natural photosynthesis, which can convert solar energy to carbohydrates or even hydrogen for easy storage and human consumption. New renewable energy forms (geothermal, solar energy, wind) only account for roughly $1.1 \%$ of the primary energy consumed in the world [6]. IPCC estimates that direct solar energy constitutes only $0.1 \%$ of the primary energy supply [7].

The path to a solar future is long, and significant amounts of work, research and development remain before solar energy will be a major energy supplier. It is also necessary to investigate solar energy feasibility using a life-cycle perspective. Power plant installations consume concrete, steel, plastics and similar everyday materials that are available in relative abundance and can be easily produced. Other materials are uncommon or even rare and can only be produced in small volumes or by complex measures. Some of these rare materials, mainly metals, are essential parts in certain solar energy technologies.

\section{Aim of This Study}

Historically, the most important obstacle for solar energy has been high costs in relation to competing energy sources. If economics are disregarded and future solar energy systems assumed to achieve a globally significant scale, the underlying reliance on rare metals might appear as one limiting factor. Ruthenium, gallium, indium and several other metals are essential components of certain solar energy technologies, such as dye-sensitized cells, thin-film cells and other innovative solar energy technologies. More general approaches have also raised the importance of rare metals for high technology such as the CRM Innonet (Critical Raw Materials Innovation Network) financed by the European Commission [8].

The infrequent occurrence of these rare materials makes it necessary to ask whether they could limit the growth of future solar energy expansion plans. Some researchers have already considered material constraints for future solar energy applications [9-12]. There are assessments of natural resource requirements for renewable energy systems, but they often dismiss potential resource constraints on inadequate grounds $[13,14]$. 
In this study, geological endowment of important minerals and the required production methods for obtaining usable products are discussed. Reserve and resource data were compiled from various geological assessments, mainly from the United States Geological Survey [15]. Based on the findings, rough estimates are calculated for possible electricity production based on respective PV technologies. The findings are finally discussed from a sustainability perspective.

\section{Solar Energy and Rare Metals}

The resource base for solar energy can be regarded in practical terms as limitless. However, due to the dilute nature of solar energy, only a small fraction of this energy flow can be transformed into a form usable for society. A useful metaphor is the distinction between tank and tap. Although the tank may be enormous, it is the size of the tap that matters for users. It is only incoming solar radiation that can be transformed into useful energy that matters for society. Thus, electricity is the required output from most solar energy systems.

Some solar thermal technologies aim to use the heat of solar radiation for direct heating or for powering conventional steam cycles. These systems generally rely on mirrors that concentrate solar energy on a single point or a line. Fresnel lenses and parabolic troughs are simple and inexpensive approaches that can achieve temperatures of $400-600{ }^{\circ} \mathrm{C}$. Point focusing systems are more complex, but can reach temperatures as high as around $1200{ }^{\circ} \mathrm{C}$. Solar-powered Stirling engines [16], parabolic trough systems [17], and concentrating solar power systems [18] have all been discussed more comprehensively by others. The mirrors are plated with silver due to the high optical reflectivity of this metal. Silver is not investigated in further detail in this study, but a recent analysis indicated that silver could form a serious bottleneck for the construction of concentrated solar power on a large scale [19].

Photovoltaics (PV) or solar cells are alternative ways of harvesting solar energy by converting light directly into electricity. Today, roughly $90 \%$ of the PV market is dependent on silicon [20]. Current and foreseeable solar energy markets will probably be dominated by silicon technologies. Silicon-based PV systems, forming the first generation of solar cells, will not be discussed in any detail since silicon is a common material. However, silicon technologies commonly use silver as an electrode material and this dependence is discussed in detail by Grandell and Thorenz [19].

Thin-film photovoltaics are referred to as second generation PV technologies. These involve several approaches dependent on rare metals. Third generation photovoltaic technology has currently reached a pre-market stage. Such technologies include dye-sensitised solar cells (DSSC), organic solar cells, and other novel approaches.

\subsection{Thin-Film Solar Cells}

Thin-film cells consist of thin photoactive layers, typically in the range of 1-4 $\mu$ m thick, leading to a light-weight structure. A semiconducting material is deposited on a common material such as glass or polymer. The need for semiconducting material is greatly reduced and could be up to $99 \%$ less compared to c-Si based technology [21]. However, cost advantages from low material use are somewhat offset by a lower electricity generation efficiency.

Silicon thin-films can be produced by chemical vapour deposition. Depending on the process, one can obtain amorphous, microcrystalline or polycrystalline structures. The solar cells made from these 
materials tend to have lower energy conversion efficiency than bulk silicon, but the production technology is very cost effective. The semiconducting material can be deposited on cheap materials, and both flat and curved surfaces are possible. As a transparent conducting oxide, typically an indium-tin-oxide (ITO) film with a thickness of $60 \mathrm{~nm}$ will be sputtered on the p-side of the semiconductor [22]. Amorphous silicon suffers from optically induced conductivity changes that lead to efficiency losses, resulting from the Staebler-Wronski effect [23], but this can be alleviated by doping Ge into the structure. The efficiency of the cells is in the range of $11.6 \%$ [24].

Tellurium is classified as a critical metal [21], and is used in cadmium-telluride (CdTe) technology, which is currently the most commercially successful thin-film application in the market. The band gap of CdTe cells is $1.4 \mathrm{eV}$, which is very close to the ideal value of $1.5 \mathrm{eV}$ [25]. Modules have achieved $17.5 \%$ efficiencies and the best reported cell efficiencies are as high as $20.4 \%$ [24].

CIGS cells are another successful thin-film technology based on a compound semiconductor made of copper, indium, gallium, and selenide. Copper/indium/selenide (CIS) and copper/gallium/selenide (CGS) form a solid solution with the chemical formula of $\mathrm{Cu}(\mathrm{InxGaz}) \mathrm{Se} 2$, where the value of $\mathrm{x}$ can vary from 1 (pure copper indium selenide) to 0 (pure copper gallium selenide). The material is a tetragonal chalcopyrite crystal structure, and a band gap can be varied between $1.04 \mathrm{eV}$ (CIS) and $1.7 \mathrm{eV}$ (CGS) through different material combinations [25]. Recently 15.7\% module efficiency has been reported [24]. Selenide can also be substituted by sulfur.

\subsection{Dye-Sensitized Solar Cells}

A dye-sensitized solar cell functions on a different principle than first and second generation technologies. The incoming light is absorbed by a dye sensitizer that is anchored to the surface of a mesoporous oxide film, typically $\mathrm{TiO}_{2}$. The dye gets excited by a photon, and the resulted electron is injected into the conduction band of the film. The electrons diffuse to the anode and are conducted over an external load to the cathode. The construction of the solar cell and its operation principle are explained in detail by Gong [26].

The appeal of dye sensitized solar cells is that they rely on fairly abundant and inexpensive materials. Manufacturing does not require elaborate equipment, and the simplicity of this type of solar cell can potentially lead to good price/performance ratio. However, the most efficient cells generally rely on dyes that are derived from rare metals.

The dye is essential for photovoltaic performance and needs to be carefully selected to fulfill several technical requirements related to light absorption, ability to anchor the dye on the semiconducting oxide, electron transfer properties between the dye and the semiconductor oxide and stability. Thus far, the dyes are based on metal complexes of ruthenium. These dyes are superior to all other known dyes in terms of light absorption. The highest performance achieved is $11.1 \%$, exhibited by the black dye, an atrithiocyanato-ruthenium complex [26]. Other approaches on an organic metal-free basis are being developed [27].

\subsection{Concentrating Photovoltaic Technology}

The idea of a concentrating photovoltaic system is to generate concentrated illumination with the help of systems of lenses or mirrors. The concentration factor can vary from 2 suns (low concentration) 
to 100 suns (medium concentration) or up to 1000 suns (high concentration). The concentrated solar radiation is then directed to a small area of high-efficiency multijunction (MJ) solar cells.

Multijunction systems are currently the most proficient PV systems and can reach over 44\% efficiency [24]. The fundamental difference between multi-junction solar cells and c-Si solar cells is that there are several junctions connected in series instead of one. This is to better cover the solar spectrum. To achieve a working MJ cell, various suitable materials are placed in layers. Each layer is optically in series, with the highest band gap material at the top. The first junction receives the entire incoming spectrum. Photons above the band gap of the first junction are absorbed in the first layer. Photons below the band gap of the first layer pass through to the lower layers to be absorbed there.

The thermodynamic Carnot cycle efficiency can be approached if all solar photons can be converted to electricity. In theory, it can be shown that $59 \%$ efficiency can be achieved with four junction devices [28] and as the number of junctions approaches infinity, the efficiency can reach as high as $68 \%$ [29]. However, it is difficult to construct such optoelectronically matched junctions, and thus commercial devices are either tandem or triple-junction cells. Typical materials used in multijunction cells are InGaP (band gap $1.67 \mathrm{eV}$ ) for top layers, GaInAs or GaAs $(1.18 \mathrm{eV})$ for middle layers and $\mathrm{Ge}$ $(0.66 \mathrm{eV})$ as a bottom layer [30].

\subsection{Emerging Solar Cell Technologies}

There are various emerging solar cell technologies, still far from commercial markets. Organic photovoltaics (OPV) are based on cheap, abundant, non-toxic materials and a high-speed roll-to-roll manufacturing process. However, problems related to low conversion efficiency and instability over time make it difficult to foresee the future potential of the technology. Other novel technologies still in the fundamental development phase include quantum dots or wires, quantum wells, and super lattice technologies [21].

\subsection{Artificial Photosynthesis}

Technologies aimed at mimicking photosynthesis are also a way of converting solar energy to satisfy human needs. These approaches are commonly grouped in a field known as artificial photosynthesis. They are not directly similar to photovoltaics, but also tend to rely on rare metals.

Natural photosynthesis uses light-harvesting complexes to collect incident photons, which participate in chemical reactions to produce carbohydrates and oxygen from carbon dioxide. However, natural photosynthesis observed in plants has very low efficiencies (typically $\sim 1 \%$ ) for biomass production and this has stimulated great interest in creating an artificial counterpart with higher efficiency [31]. Artificial photosynthesis could be used to convert and store solar energy as carbohydrates or alternatively as hydrogen. In theory, this could solve many of the intermittency problems that are related to more conventional forms of solar energy. The rare metal ruthenium is a key component in many approaches and may be a limiting factor for implementation. Other platinum-group metals and nickel might constitute alternatives [32]. 


\section{Occurrence of Rare Elements}

Many of the rare metals used in solar cells occur in low concentration within the Earth's crust. Most do not occur as primary ores, and are only found as by-products associated with primary base metal and precious-metal ores. This section briefly reviews the geological abundance of some rare elements used in solar energy applications.

Cadmium is primarily extracted from zinc ores, mainly from sphalerite deposits. Cadmium has chemical properties similar to zinc's and can replace it in crystal lattices of certain ores. Sphalerite ore contains $3 \%-11 \%$ zinc along with $0.0001 \%-0.2 \%$ cadmium and less than $0.0001 \%-0.01 \%$ indium, copper, silver, iron, gold, germanium and thallium [12]. Carbonate-hosted sphalerite in Mississippi Valley-type (MVT) deposits have high cadmium concentrations, while sedimentary exhalative (sedex) occurrences have low concentrations [33]. Certain coals can also have relatively high cadmium content, but they are all subeconomic for the moment [15].

The estimated abundance of indium is $0.1 \mathrm{ppm}$ in the earth's crust, making it the 69th most abundant element [34]. However, indium is highly dispersed in nature and enriched deposits of economic interest are rare. A comprehensive overview of indium and its mineralogy has been conducted by Schwarz-Schampera and Herzig [35]. Indium is only recovered as a by-product from zinc-sulfide ore mineral sphalerite [15]. Indium can also be found as trace element in deposits of other base metals, but it is generally difficult to process and extract it economically.

Gallium can be found in low concentration in many ores. Burton et al. [36] investigated the presence of gallium in 280 minerals and determined the crustal abundance to be $17 \mathrm{ppm}$, while Emsley [34] gives an average concentration of $18 \mathrm{ppm}$. Andersson [9] notes that gallium is approximately as abundant as copper but seldom forms any enriched mineralisation. In contrast, copper is enriched by a factor of 200-800 in mined ores, while gallium rarely occurs in minable concentrations. Such differences will have significant repercussions for production feasibility. Gallium only seems to be concentrated in certain oxide minerals, primarily bauxite but also corundum and magnetite [36]. Bauxite ores contain from $0.003 \%$ to $0.008 \%$ gallium [37]. World resources are estimated to be 2 million tonnes in bauxite deposits and 6500 tons in zinc deposits [38]. Recent works have also identified certain coals as potentially massive sources [39], although only a small part of the gallium can be recovered in practice [15].

Germanium occurs primarily through silicate minerals in the earth's crust due to ionic substitution with the silicon ion. Typical concentrations are a few ppm. Moskalyk gives a mean concentration of 6.7 ppm [40], while Höll et al. states an average of 1.7 ppm [41]. The highest enrichments can be found in non-silicate formations as zinc/copper-sulphides, primarily low-iron sphalerite, or in certain coals [42]. In addition, fly ash from certain coals can contain as much as $1.6 \%-7.5 \%$ germanium [40], and may be an important source if proper recovery methods are developed. Furthermore, high concentrations have been commonly found in iron-nickel meteorites, and this suggests that major shares of the earth's germanium may reside in the planetary core [42]. A review of germanium and its occurrence have been provided by Höll et al. [41].

Both selenium and tellurium are found in low concentrations in copper ores and commonly recovered as side-products from copper refining [43]. Additionally, selenium occurs at concentrations between 0.5 and $12 \mathrm{ppm}$ in various coals, which equals a much larger resource base than the worlds 
copper ores (USGS, 2015) [15]. Yodovich and Ketris reviewed selenium in coal and pointed out that coal ash has enriched selenium concentrations [44]. However, recovering selenium from coal does not appear likely due to the high volatility of the material [12]. World selenium reserves are estimated to be 120,000 tons derived from copper ores [15].

Tellurium is the 72nd most abundant element in the Earth's crust, with $5 \mathrm{ppb}$. Some tellurium minerals are found in nature such as calaverite, sylvanite or tellurite, but are not mined [34]). USGS estimates the world tellurium reserves to be 24,000 tons based on identified copper ores [15], but also mentions the possibility of recovering tellurium from certain gold-telluride or lead-zinc ores. Over $90 \%$ of tellurium is produced from anode slimes from copper refining, which can contain as much as $8 \%$ tellurium [34].

Ruthenium and platinum are rare elements that occur together with other platinum-group metals. The largest platinum-group metal deposit is the Bushveld Complex in South Africa [15]. Nearly 90\% of the world's known platinum reserves are located in South Africa [45], while other deposits can be found in Russia, North America, and Zimbabwe, and only to a smaller degree in other countries [15]. Andersson highlighted how this dominance of a single country would make platinum group metal supply sensitive to monopolistic behavior and geopolitical issues [9].

\section{Production and Future Outlooks}

Mining and processing of ore deposits requires mining, rock blasting, transportation, crushing, milling, and different chemical procedures. The conversion form ore to a marketable commodity is usually an energy intensive process. Rosa and Rosa gave a formula for the energy cost of mining and refining a substance [46]:

$$
J=C / g Y
$$

where $J$ is the energy cost of unit mass of the desired product, $C$ the energy expenditure of mining, milling and concentrating per unit mass of the actual ore, $Y$ is the joint recovery rate or process yield and $g$ denotes the grade or mass fraction of the substance in the ore. From this it is evident that moving in to low grade ores inescapably requires more energy input per unit mass unless technological improvements can offset the disadvantages caused by lower ore grades. Rosa and Rosa and references therein discuss this topic in more detail [46]. As a consequence, production of materials derived from low concentration ores will be sensitive to future energy prices, especially when moving towards lower and lower ore grades.

The rare materials used in several solar technologies chiefly occur as byproducts of base metal ores. Platinum is an exception; PGMs are mined as well as by-products and primary products. As a result, future production of those materials is intrinsically linked to the base metal production. This relationship makes it challenging to significantly increase production of by-products without increasing the production of the main product. Fthenakis have also highlighted the opposite relation and how an increasing production of base metals unavoidable generates by-products, such as cadmium, that either must be put to constructive use or disposed of in an environmentally acceptable way [43]. 


\subsection{Base Metal Production}

About $90 \%$ of all zinc production is accomplished by the electrolytic process, while $10 \%$ rely on older pyrometallurgical treatment. For lead production, after sintering, lead is usually smelted in a blast furnace. Smelting frees the metal from the oxidized form. About half of lead originates from recycled sources [47]. Copper production is mainly $(80 \%)$ done by pyrometallurgical processing of sulphide ores, with the remainder being hydrometallurgical treatment of oxide ores. Fthenakis et al. provide a comprehensive overview of copper and zinc production and their flow schemes [12]. Treatment of various residues is the main feedstock for recovering numerous other metals, such as indium or cadmium, as by-products.

World production of copper, lead, and zinc can be seen in Figure 1. More than half of the present world mine production of lead comes from China [15]. In addition, 58\% of the global zinc mine production originates from China, Australia and Peru. Nearly 55\% of present world copper production originates from Chile ( $31 \%$ alone), USA, Peru, and China. Global production of base metals is not evenly distributed, intrinsically affecting the recovery and supply of by-products.

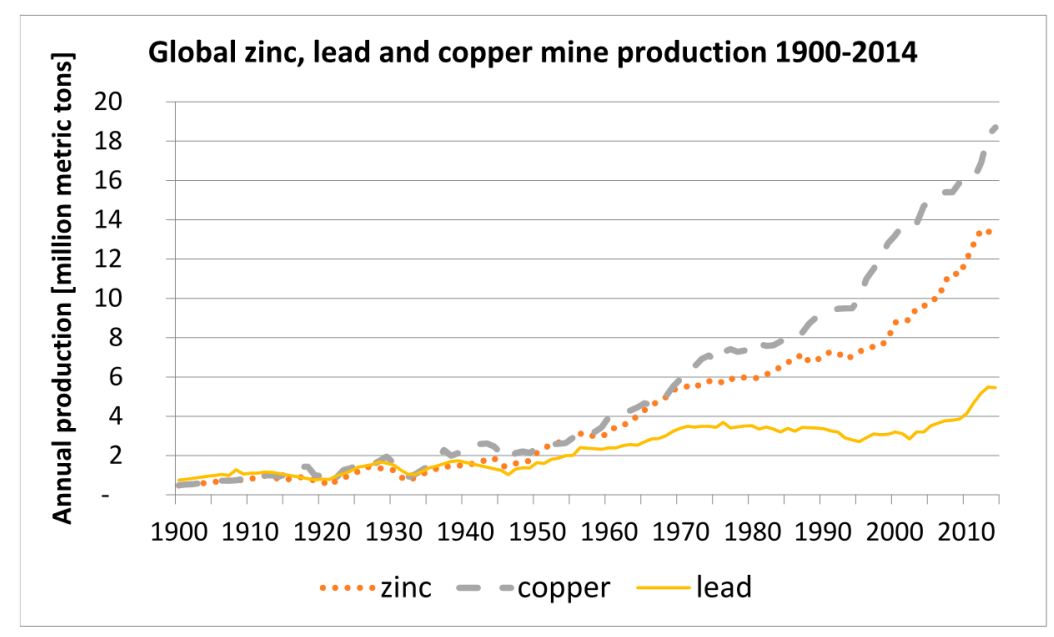

Figure 1. World production of zinc, lead and copper from 1900 to 2014 [15].

A similar situation can be seen for bauxite mining and aluminium production. Bauxite is converted via Bayer process to alumina, an aluminium oxide, which is further electrolysed to obtain pure metal. World production of bauxite and aluminum has increased significantly after 1950 (Figure 2). Australia and China presently account for roughly $55 \%$ of the world bauxite production, and China alone also accounts for $47 \%$ of global aluminum production [15].

World production of base metals is unevenly distributed with significant concentration in a few countries, resembling the situation for world supply of fossil fuels [48,49]. Occurrences have been identified in all over the world, but many of them are sub-economic or otherwise unattractive deposits. However, it should be specifically noted that geological abundance has little to do with the likelihood of significant future production, as actual recovery must be both technically and socioeconomically feasible. As a consequence, seemingly abundant but dilute formations may never be attractive for mining, while scarce but highly concentrated deposits can be attractive to exploit. 


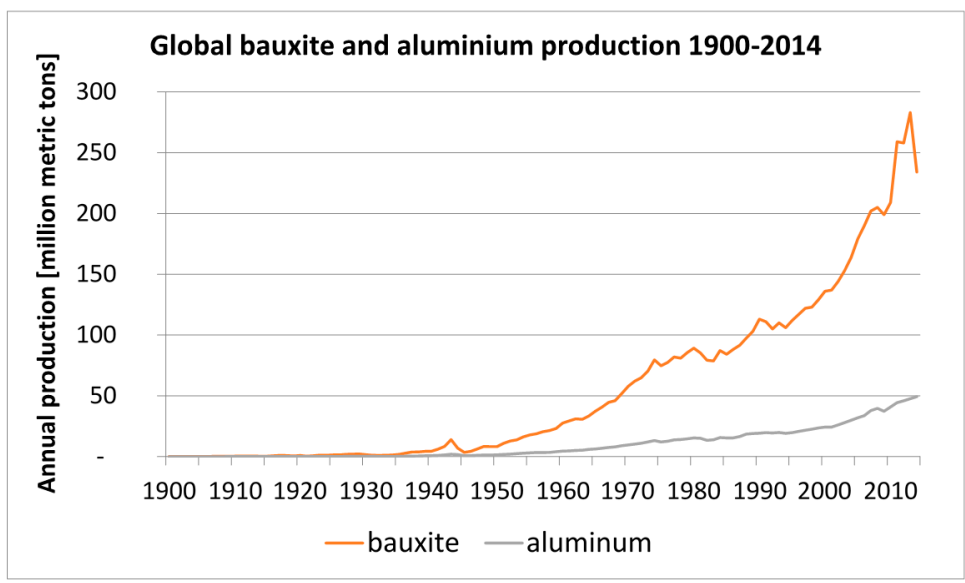

Figure 2. World production of aluminum and bauxite from 1900 to 2014 [15].

\subsection{Recovery of By-Products}

Hartman finds that significant shares of the gallium reserves will not be produced in any foreseeable time, simply because they are a by-product of bauxite mining and have to be primarily governed by future aluminum demand [50]. Gallium is extracted from bauxite in conjunction with aluminum oxide based on the Bayer process [37]. The second recovery method involves electrolytic processes with mercury, allowing gallium extraction after addition of caustic soda. Despite environmental challenges surrounding mercury, this method is employed many countries. The last recovery method is based on chelating agents and addition of diluted acids, eventually making gallium recoverable by direct electrolysis. Moskalyk has provided a more comprehensive overview of the production methods and the worldwide suppliers of gallium [37]. World gallium production for the last 100 years can be seen in Figure 3. Gallium is produced by a small number of producers and world primary production is currently in the order of 400 tons, with additional gallium derived from recycling of scrap electronics containing GaAs.



Figure 3. World production of gallium, germanium and tellurium from 1900 to present. Tellurium production began in the 1930s. Important countries such as China and USA are not included in the tellurium production figures, which therefore underestimate reality. Gallium and germanium have been increasing for the last decades [15]. 
Germanium production usually consists of two stages, where the first step creates a concentrate and the second is the actual recovery. Hydrometallurgical processes using precipitation are generally preferred. In comparison, thermal and pyrometallurgical processes have inherent complications with the volatility of germanium oxides and sulphides and their environmental challenges. Moskalyk compiled a review of worldwide germanium production and suppliers [40]. Historical production of germanium since the late 1950s can be seen in Figure 3.

More than $90 \%$ of the world's tellurium is recovered from anode slimes collected from electrolytic copper refining, and the remainder is a by-product of lead refineries and from bismuth, copper, and lead ores [15]. Anode slimes are primarily treated to recover gold, silver, platinum, palladium and rhodium, while selenium and tellurium are of secondary priority [12]. The actual percentage of tellurium recovery from anode slimes is variable and depends on concentration. Recovery is done by cementation with copper to form copper telluride. This is further processed to a sodium telluride solution with caustic soda and air. In the next step pure tellurium metal or tellurium oxide are produced for solar cell applications. Fthenakis et al. have compiled a more detailed overview of tellurium production [12]. Important tellurium producing countries are Japan, Russia, and Canada [15].

Cadmium production originates from smelting of zinc and lead-zinc ores. The cadmium sponge, a by-product from precipitating zinc sulphate solution at the zinc smelter is almost pure cadmium (more than 99\% purity) and is used as the main feedstock in cadmium recovery facilities [43]. Fumes and dust from zinc sinter plants are also important feedstock for further purification. Comprehensive overview of cadmium recovery processes have been made by Safarzadeh et al. [51]. Commonly, cadmium is seen as a highly toxic metal and cadmium disposal is connected to environmental hazards. Thus, recovering cadmium from primary and secondary sources is of great importance [51]. China and South Korea are the largest producers and account for roughly half of world production, followed by Kazakhstan, Canada, Japan and Mexico [15]. Additionally, recycling of Ni-Cd batteries is also a source for cadmium.

Indium production is similar to cadmium and recovery is chiefly done as a by-product from collected dust, fumes, and other residues from zinc refining. Advantages in indium recovery processing have now increased, and extraction rates have reached $75 \%$ of the treatable residues [52]. Many details on the actual production technology are proprietary, but some general recovery methods based on standard methods and general information from producers have been compiled by Fthenakis et al. [12]. More discussions on indium production and worldwide suppliers have been conducted by Alfantazi and Moskalyk [52] and Fthenakis et al. [12]. More than 50\% of the world's primary indium production originates from China [15].

Mined platinum group metal (PGM) ores are initially crushed and grinded before being concentrated in a froth flotation process. Addition of water, air, and chemicals created a froth containing the PGM metals and is collected. Following the matte-smelting process, high purity platinum is refined through a series of hydrometallurgical processes [45]. Ruthenium is recovered as a byproduct during platinum-group metal refining. This is mainly done through insolubility in aqua regia, which leaves a solid residue that can be refined to obtain pure ruthenium, osmium, and other commonly associated metals. Solvent extraction has been described as a method [53], although very little details are available for ruthenium refining methods presently in use. Figure 4 shows the production of indium, selenium and PGMs. 


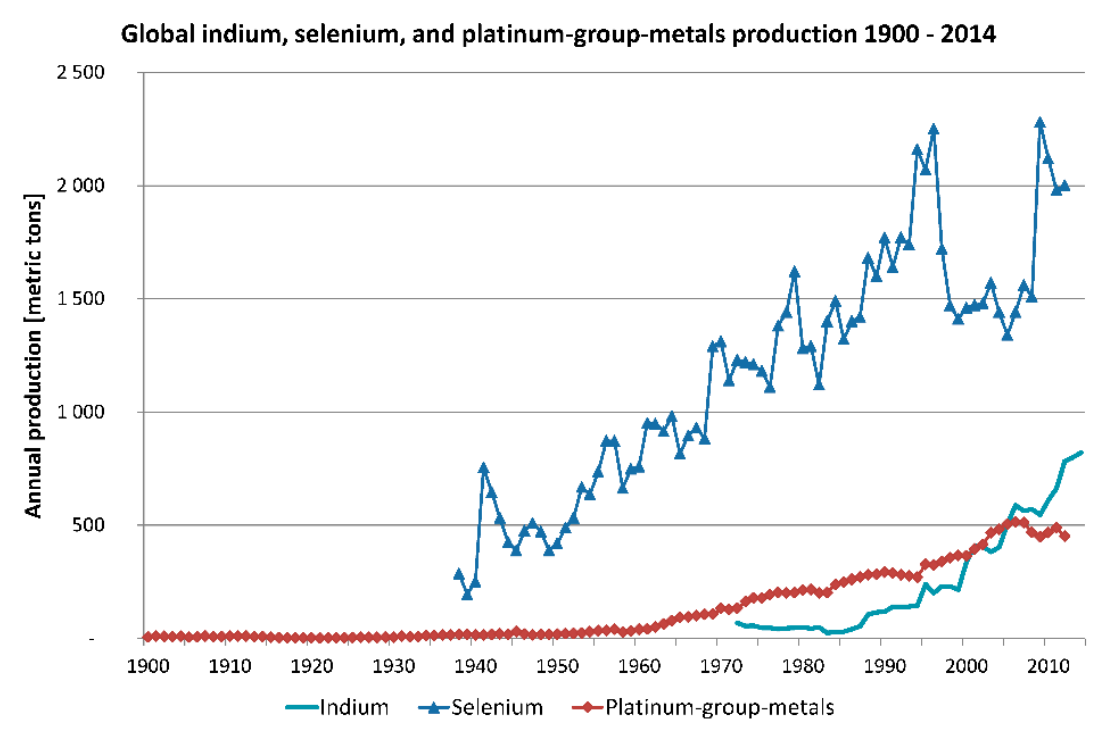

Figure 4. World production of indium, selenium and platinum group metals (including platinum and ruthenium) for 1900 to present. Selenium (data does not include production in USA) production peaked in 1990 and has stabilized somewhat lower than the peak level for more than a decade. Indium shows a rapid increase over the last decades [15].

\subsection{Competition from Non-Solar Energy Sectors}

Many of the critical metals discussed here also have important uses other than solar energy applications. Therefore, it can be argued that the assumption that all the available reserves or production of the rare materials would go to solar energy pursuits is unrealistic. In reasonable cases, only a share of the metal flows would be available for solar energy solutions. How large this share will become is a complicated question and will be affected by several factors, such as how the metals' intensity in solar applications and the competing markets will evolve. What are the perspectives for substitution, substituting materials or substituting technologies and approaches both in the solar sector and the competing markets?

More than $80 \%$ of the world's cadmium is used to make rechargeable batteries, but other important uses are for pigments, coatings, and platings, stabilizers for plastics, alloys and photovoltaics. However, due to environmental and health concerns significant effort has been made to replace cadmium with other less toxic substances [15].

Gallium has been described as a backbone of the electronics industry and constitutes an important component in semiconductors, diodes and laser systems. Gallium arsenide for semiconductor applications makes up $95 \%$ of global gallium consumption [37]. Only some $2 \%$ of the produced GaAs is consumed by photovoltaic industry, whereas other uses include electric circuits, laser technology, diodes, and LED lights [22].

The photovoltaic industry is the most important end-use segment of tellurium with a $40 \%$ market share. It is followed by thermoelectric modules, which function as a small heat pump and are based on semiconducting materials. Other uses include metallurgy and the rubber industry [54]. Currently photovoltaics form a niche market for selenium, whereas $40 \%$ of selenium is consumed for the production 
of electrolytic manganese, which is a key material component for alkaline and litium-ion batteries. Other uses for selenium are found in the glass industry, agriculture, pigments and metallurgy [54].

About $90 \%$ of indium flows in the production of ITO (indium-tin-oxide), which is a transparent, conducting foil used in flat display panels and thin-film coatings. Other end-uses include solders, cryogenics, and special alloys. The electrical industry, including photovoltaics, is responsible for only $3 \%$ of the global indium consumption [55].

The electronics industry, also including solar applications, consumes $15 \%$ of the global germanium markets. Important competing applications are found in infrared optics, fiber optics, and polymerization catalysts (together 70\% market share), whereas smaller market segments are found in phosphors, metallurgy and chemotherapy [56].

Ruthenium is used for creating wear-resistant electrical contacts, thick film chip resistors, and for various catalyst applications. The electrical industry is the most important ruthenium consuming sector, with a market share of over $60 \%$ [57]. Currently almost no ruthenium is used in the photovoltaics and solar energy industries.

In summary, many of the materials used here will be subjected to competition regarding usage. In some places it is possible to switch to substitutes, but likely several sectors will continue to rely on the same rare metals that several solar energy technologies are built around. The kind of financial repercussions this will bring should be investigated more closely and taken into account in any holistic study of economic long-term feasibility.

\subsection{Recycling of Scarce and Rare Metals}

Valero and Valero point out that there is no substitute for metals if they are irretrievably dispersed by human use [58]. Therefore, recycling is an important factor for making the best possible use of produced metals and should be encouraged. To some extent, recycled material can also help with balancing production from mining by alleviating mismatches in supply and demand. However, recycling does not increase recoverable volumes. It is only a way to reuse some of the already mined materials again and prevent them from being locked up in scrap heaps or waste disposals. It is important to remember that recycling is only something that makes the use of materials more sustainable while it is incapable of removing intrinsic limits caused by recoverable volumes. Some of the metals discussed here are already extensively recycled or reused-gallium in particular, as the world primary gallium production capacity in 2011 was estimated to be between 260 and 320 tons, while the recycling capacity was 198 tons [15].

This analysis uses the amount of known global metals reserves or resources as bases and calculates the maximum PV electricity production, which can be achieved with the given amount of metal. One can thus argue that this approach intrinsically includes recycling with the very optimistic assumption of a $100 \%$ recycling rate.

\section{Material Consumption of Solar Technologies}

Harvest solar energy is often seen as abundant, rich, and lasting supply of energy without any practical constraints. That is not entirely true, as the conversion technologies are dependent on raw material inputs necessary for construction. Solar energy technologies harvest renewable energy, but 
there are no such things as renewable power plants. Material availability or production bottlenecks may lead to significant constraints for the necessary building components for solar energy technologies. This section explores whether scarcity of certain key materials may provide an upper limit for some selected solar energy technologies. Similar studies were performed by Andersson and others [9,59]. No good material consumption estimates could be found for artificial photosynthesis approaches, but it is expected to be at a similar magnitude as the other solar energy technologies.

Material requirement per square meter for solar energy is a key property, as the incoming energy must be harvested over large areas. Table 1 gives some estimated material consumptions for relevant technologies. These consumption figures are based on a $100 \%$ material utilization $[9,22]$, which is optimistic because it entirely ignores process losses. However, this optimistic assumption may compensate for some of the potential reductions in material requirements since year 2000.

Table 1. Estimated material consumption for selected solar energy technologies $[9,22,60]$.

\begin{tabular}{cccc}
\hline Technology & Material & Material Consumption $\mathbf{( g / \mathbf { m } ^ { 2 } )}$ & Source \\
\hline CdTe & Cadmium & 6.9 & DOE [60] \\
& Tellurium & 7.8 & DOE [60] \\
CIGS & Indium & 2.9 & Angerer et al., \& Andersson [9,22] \\
& Gallium & 0.53 & Angerer et al., \& Andersson [9,22] \\
& Selenium & 4.8 & Angerer et al., \& Andersson [9,22] \\
aSiGe & Germanium & 0.44 & Andersson [9] \\
& Indium & 0,38 & Angerer et al. $[22]$ \\
Grätzel & Ruthenium & 0.1 & Angerer et al. $[22]$ \\
\hline
\end{tabular}

Solar insolation can be as high as over $2000 \mathrm{kWh} / \mathrm{m}^{2}$ per annum at excellent sites like the desert areas of Sahara or in Australia, where clouds are virtually nonexistent. For comparison the global average insolation value is $1700 \mathrm{kWh} / \mathrm{m}^{2}$. The average value for Central Europe and Northern Europe is in the range of $1000 \mathrm{kWh} / \mathrm{m}^{2}$. The last two columns in Table 2 give the annual electricity production of the respective solar technology, assuming that $50 \%$ or $100 \%$ of the respective world material reserves are devoted to solar cell fabrication. For comparison, the present global primary energy demand is over 13,371 million tons of oil equivalents (MTOE) [6].

A more comprehensive study would naturally use more realistic assumptions about solar hours related to geographical location into account than in this study. However, we do not believe that such details would change the overall picture that material constraints pose a challenge for moving solar technology from its present small scale (134 GWp installed capacity by the end of 2013, resulting in $\sim 14$ Mtoe globally) to production of globally significant amounts of energy [61]. Even though the consumption of rare materials is only a few grams per square meter, the diffuse influx of solar energy requires large areas to provide significant energy amounts. This results in considerable material use that could possibly surpass production capacity and resource availability for rapid growth rates.

Available reserves and resources were mostly taken from the USGS where available [15]. Reserve (or resource) data on some metals did not allow the USGS to make estimates compatible with their standards. In such cases, reserve estimates were taken from other sources: ruthenium, germanium [34], indium [62], gallium [38], and germanium [63]. 
Table 2. Potential contribution to future world energy supply constrained by available reserves and resources. Three cases with $10 \%, 50 \%$ and $100 \%$ diversions to solar energy applications were considered. For comparison, world primary energy consumption in 2014 was slightly more than 13,000 Mtoe, final energy consumption 4700 Mtoe and electricity consumption 1600 Mtoe [6].

\begin{tabular}{|c|c|c|c|c|c|c|c|c|c|c|}
\hline \multirow{3}{*}{ Technology } & \multirow{3}{*}{ Material } & \multirow{2}{*}{$\begin{array}{c}\text { Global } \\
\text { Production }\end{array}$} & \multirow[t]{2}{*}{ Reserves } & \multicolumn{3}{|c|}{$\begin{array}{l}\text { Constrained } \\
\text { Contribution }\end{array}$} & \multirow[t]{2}{*}{ Resources } & \multicolumn{3}{|c|}{$\begin{array}{l}\text { Constrained } \\
\text { Contribution }\end{array}$} \\
\hline & & & & $10 \%$ & $50 \%$ & $100 \%$ & & $10 \%$ & $50 \%$ & $100 \%$ \\
\hline & & tons & tons & Mtoe & Mtoe & Mtoe & tons & Mtoe & Mtoe & Mtoe \\
\hline \multirow[t]{2}{*}{ CdTe } & $\mathrm{Cd}$ & 22,000 & $\begin{array}{c}500,000 \\
(2014) \\
\end{array}$ & 190 & 930 & 1860 & $\begin{array}{c}1,200,000 \\
(2009)\end{array}$ & 450 & 2230 & 4470 \\
\hline & $\mathrm{Te}$ & $\sim 500$ & $\begin{array}{l}24,000 \\
(2015)\end{array}$ & 8 & 40 & 80 & & & & \\
\hline \multirow[t]{3}{*}{ CIGS } & In & 820 & 11,000 & 9 & 40 & 90 & 65,000 & 50 & 260 & 510 \\
\hline & $\mathrm{Ga}$ & 440 & 6500 & 30 & 140 & 280 & N/A & & & \\
\hline & $\mathrm{Se}$ & $\sim 2000$ & 120,000 & 60 & 290 & 570 & $\begin{array}{c}\text { Se in coal } \\
\text { deposits }\end{array}$ & & & \\
\hline \multirow[t]{2}{*}{$\begin{array}{l}\mathrm{aSiGe} \text { or } \\
\mathrm{aSi} / \mathrm{nc} / \mathrm{Si}\end{array}$} & $\mathrm{Ge}$ & 165 & N/A & & & & 27,000 & 100 & 520 & 1040 \\
\hline & In & 820 & 11,000 & 50 & 250 & 490 & 65,000 & 290 & 1450 & 2900 \\
\hline Grätzel & $\mathrm{Ru}$ & 12 & 5000 & 60 & 320 & 640 & N/A & & & \\
\hline
\end{tabular}

Table 2 shows the results of the analysis in a matrix with respect to global reserves - and when possible to global resources - and with three different resource allocations to the solar sector, namely $10 \%, 50 \%$ and $100 \%$. Depending on competing end-uses for the critical metals, different resource allocations seem reasonable. Global reserves reflect those deposits, which can be mined with current technology economically. Thus, figures related to reserves show a minimum level of how much solar energy can be produced with the technologies in question. Global resources can be understood as an upper limit. The estimations are very uncertain, and for some metals, even missing, and therefore estimations based on resources should be viewed critically.

\section{Discussion}

For CdTe the constraining metal is tellurium. Currently $40 \%$ of the annual tellurium markets are consumed in the photovoltaic industry. The USGS does not give any resource estimation for reasons of data accuracy, and therefore the estimation used in the analysis refers to global tellurium reserves. In this case and assuming 50\% market share, electricity production from CdTe panels would be limited to 40 Mtoe annually. However the reserve figure considers only tellurium from the anode slimes of copper refining with a currently relatively low recovery rate of approximately $40 \%$. Fthenakis argues that the recovery rate could technically be as high as the recovery rate for copper in the electrolytic refining process, $80 \%$. Even higher rates, such as 95\% for gold, would technically be possible [64]. The question is more economical in nature, i.e., whether the price of tellurium is a sufficient incentive for higher recovery rates. In addition to copper mines, other geological reserves for tellurium exist, such as by-product in lead-zinc ores, primary tellurium mines, ocean crusts and sour oil and gas [65]. 
However, no resource estimation exists for these additional sources and therefore they are excluded from the analysis. Also the material intensity has a potential for remarkable improvements by a factor of four as shown by Woodhouse et al.: the efficiency can be almost doubled while, at the same time, the active layer thickness can be cut to $1 \mu \mathrm{m}$. It is however, not yet clear to what extent this potential will become reality for commercial applications [66]. In the optimistic case, this would allow more than 300 Mtoe or $3500 \mathrm{TWh}$ of annual electricity production. This is comparable with the cumulative capacity of 0.9-1.8 TWp until 2050 modelled by Fthenakis [64].

Grätzel cells are constrained by the availability of ruthenium, which is currently used mostly in the electrical industry. Even if half of the known reserves were devoted to solar cell production, only some 300 Mtoe could be annually produced.

CIGS technology is constrained by both indium and gallium. Indium is consumed currently to $90 \%$ for ITO production. Even if all available indium resources were to be used in the solar industry-an unrealistic assumption - a maximum of some 500 Mtoe as annual production seems plausible. Another technology dependent on indium is based on amorphous silicon. The dependency on germanium can be avoided by a tandem structure, which also has a stabilizing effect on the efficiency of the module. Thus, the constraining metal is indium. ITO films are also used beside solar energy in various other application areas such as flat panel displays, plasma displays or touch panels. Therefore, the upper limit for electricity produced by amorphous silicon seems to be in the range of some hundreds of Mtoe annually.

Silicon is the second most abundant element in the Earth's crust, making up approximately one fourth of it when measured by mass. However, Grandell and Thorenz foresaw a problem with scaling up silicon technologies due to material constraints from silver, commonly used as an electrode material, and estimated the upper limit to be some 13,000 TWh annual electricity production or 1000 Mtoe [19]. This estimate is based on a very low silver content $\left(0.82 \mathrm{~g} / \mathrm{m}^{2}\right)$, which already reflects a technical approach to reduce silver consumption, such as the "wrap through technology" or substitution of silver with copper, both of which are currently in development stage. Indium currently used in ITO could possibly be replaced by FTO (fluorine doped tin oxide) and AZO (aluminium doped zinc oxid).

The above mentioned figures can be compared with world primary energy consumption (13,000 Mtoe), world final energy consumption (4700 Mtoe) or world electricity production (1600 Mtoe). All figures refer to the year 2014 [6]. The world energy sector is expected to experience a shift away from fuels towards electricity due to climate concerns and energy security questions. Currently one third of the global final energy consumption is due to the traffic sector, mainly consisting of oil consumption. In the future this will be to a large degree electricity consumption. Additionally, the rising economies in the developing world are another factor stressing the need for more electricity production. If we assume that $50 \%$ of the currently known global resources of Te and $10 \%$ of the resources of Ru and In are devoted to the solar industry, we could generate 500 Mtoe, or in the most optimistic case, 800 Mtoe of solar electricity annually. Additionally c-Si technology provides more potential for PV electricity generation, but the technology is constrained by silver dependence and it remains to be seen to which degree new approaches with decreased silver content will enter the market.

If a future global energy system based on solar energy is sought, it is vital to consider material challenges or alternatively focus on other technological pathways than those explored here. A 
practical path for future research is use of alternative and more abundant materials if solar energy is to become a sustainable backbone of the global energy system. Todorov et al. showed that thin-films based on the abundant copper-zinc-tinchalcogenide kesterites $(\mathrm{Cu} 2 \mathrm{ZnSnS} 4$ and $\mathrm{Cu} 2 \mathrm{ZnSnSe} 4)$ could reach over $9.6 \%$ conversion efficiency [67]. The selenium usage in these cells could in theory be entirely replaced by sulphur, creating a thin-film cell only relying on abundant materials. For certain other technologies, such as dye-sensitized cells, it would be fairly easy to replace scarce or rare materials with more abundant ones. Organic dyes that do not required noble metal complexes have been discussed by Hara et al. [68].

\section{Conclusions}

When summarizing several promising solar energy technologies, it was found that they rely on several critical metals as important components. Many technologies are likely going to face constraints in material supply if scaled to the TW level (Table 2). Material questions are an important factor for the development of several future solar energy technologies. Without a holistic treatment of required material questions, solar energy production outlooks should be regarded with sound skepticism. Increasing demand for scarce materials may become a factor of importance in the future. Many of the unusual materials are key ingredients to various technologies, including several of the more promising solar energy applications.

There are prospects for reducing material requirements by significant amounts for CIGS and CdTe by utilizing even thinner films and advanced light trapping technologies [9,66]. Large scale development of the studied solar technologies would likely require either substantial reductions in material intensity, technical advancements in electricity generation efficiency or increased world mineral reserves as well as significant increases in mine production.

These results points to obstacles for certain solar technologies when it comes to reaching a TW scale. Indium, tellurium, germanium and ruthenium are in potentially tight supply. Research and development paths that aim to circumvent the dependence on rare materials are generally encouraged from a longer perspective. Additionally, the constraints imposed by nature on critical metals may direct solar energy research to usage of other materials in the long run. Solar energy technologies that do not require rare elements are the only feasible technology for large-scale implementation. CdTe, CIGS, a-Si and ruthenium-based Grätzel cells will all be limited by material availability and only able to provide small shares of the present world energy consumption (Table 2). It is important to use CIGS, CdTe and the other technologies discussed in this study as bridges to alternative and less limited solar energy applications.

\section{Acknowledgments}

Financial support for the work has been provided by the Fortum Foundation.

\section{Author Contributions}

Mikael Höök started with data collection which was finalized and analysed by Leena Grandell. The writing of the article was done by both authors. 


\section{Conflicts of Interest}

The authors declare no conflict of interest.

\section{References}

1. International Energy Agency (IEA). World Energy Outlook 2014; Organisation for Economic Co-operation and Development OECD/IEA: Paris, France, 2014.

2. Miller, R.G.; Sorrell, S.R. The future of oil supply. Philos. Trans. R. Soc. A 2014, doi:10.1098/rsta.2013.0179.

3. Höök, M.; Tang, X. Depletion of fossil fuels and anthropogenic climate change-A review. Energy Policy 2013, 52, 797-809.

4. Edenhofer, O.; Pichs-Madruga, R.; Sokona, Y.; Farahani, E.; Kadner, S.; Seyboth, K.; Adler, A.; Baum, I.; Brunner, S.; Eickemeier, P.; et al. (Eds.) Climate Change 2014: Mitigation of Climate Change. Contribution of Working Group III to the Fifth Assessment Report of the Intergovernmental Panel on Climate Change; Cambridge University Press: Cambridge, UK; New York, NY, USA, 2014.

5. Ion, D.C. World energy supplies. Proc. Geol. Assoc. 1979, 90, 193-202.

6. International Energy Agency (IEA). Key World Energy Statistics 2014. Available online: http://www.iea.org/publications/freepublications/publication/key-world-energy-statistics-2014.html (accessed on 20 March 2015).

7. Edenhofer, O.; Pichs-Madruga, R.; Sokona, Y.; Seyboth, K.; Matschoss, P.; Kadner, S.; Zwickel, T.; Eickemeier, P.; Hansen, G.; Schlömer, S.; et al. (Eds.) IPCC Special Report on Renewable Energy Sources and Climate Change Mitigation; Prepared by Working Group III of the Intergovernmental Panel on Climate Change; Cambridge University Press: Cambridge, UK; New York, NY, USA, 2012; p. 1075.

8. CRM Innonet. Available online: http://www.criticalrawmaterials.eu/ (accessed on 13 May 2015).

9. Andersson, B.A. Materials availability for large-scale thin-film photovoltaics. Prog. Photovolt. Res. Appl. 2000, 8, 61-76.

10. Feltrin, A.; Freundlich, A. Material considerations for terawatt level deployment of photovoltaics. Renew. Energy 2008, 33, 180-185.

11. Fthenakis, V. Sustainability of photovoltaics: The case for thin-film solar cells. Renew. Sustain. Energy Rev. 2009, 13, 2746-2750.

12. Fthenakis, V.; Wang, W.; Kim, H.C. Life cycle inventory analysis of the production of metals used in photovoltaics. Renew. Sustain. Energy Rev. 2009, 13, 493-517.

13. Davidsson, S.; Höök, M.; Wall, G. A review of life cycle assessments on wind energy systems. Int. J. Life Cycle Assess. 2012, 17, 729-742.

14. Davidsson, S.; Wachtmeister, H.; Grandell, L.; Höök, M. Growth curves and sustained commissioning modelling of renewable energy: Investigating resource constraints for wind energy. Energy Policy 2014, 73, 767-776.

15. U.S. Geological Survey (USGS). Mineral Commodity Summaries. Available online: http://minerals.usgs.gov/minerals/pubs/mcs/ (accessed on 30 March 2015). 
16. Kongtragool, B.; Wongwises, S. A review of solar-powered Stirling engines and low temperature Differential Stirling engines. Renew. Sustain. Energy Rev. 2003, 7, 131-154.

17. Price, H.; Lüpfert, E.; Kearney, D. Advances in Parabolic Trough Solar Power Technology. J. Sol. Energy Eng. 2002, 124, 109-125.

18. Treib, F.; Nitsch, J.; Kronshage, S.; Schillings, C.; Brischke, L.A.; Knies, G.; Czisch, G. Combined solar power and desalination plants for the Mediterranean region-Sustainable energy supply using large-scale solar thermal power plants. Desalination 2003, 153, 39-46.

19. Grandell, L.; Thorenz, A. Silver supply risk analysis for the solar sector. Renew. Energy 2014, 69, 157-165.

20. Fraunhofer ISE. Photovoltaics Report (2014) Updated: 24 October 2014. Available online: http://www.ise.fraunhofer.de/en/downloads-englisch/pdf-files-englisch/photovoltaics-report-slides.pdf (accessed on 25 March 2015).

21. International Renewable Energy Agency (IRENA). Renewable Energy Technologies: Cost Analysis Series. Volume 1: Power Sector. Solar Photovoltaics. Available online: https://www.irena.org/DocumentDownloads/Publications/RE_Technologies_Cost_AnalysisSOLAR_PV.pdf (accessed on 25 March 2015).

22. Angerer, G.; Erdmann, L.; Marschneider-Weidemann, F.; Scharp, M.; Lüllmann, A.; Handke, V.; Marwede, M. Rohstoffe für Zukunftstechnologien. Einfluss des branchenspezifischen Rohstoffbedarfs in rohstoffintensiven Zukunftstechnologien auf die zukünftige Rohstoffnachfrage; Fraunhofer IRB Verlag: Stuttgart, Germany, 2009.

23. Staebler, D.L.; Wronski, C.R. Optically induced conductivity changes in discharge-produced hydrogenated amorphous silicon. J. Appl. Phys. 1980, 51, 3262-3268.

24. Green, M.A.; Emery, K.; Hishikawa, Y.; Warta, W.; Dunlop, E.D. Solar cell efficiency tables (version 44). Prog. Photovolt Res. Appl. 2014, 22, 701-710.

25. Kemell, M.; Ritala, M.; Leskelä, M. Thin Film Deposition Methods for CuInSe 2 Solar Cells. Crit. Rev. Solid State Mater. Sci. 2007, 30, 1-31.

26. Gong, J.; Liang, J.; Sumathy, K. Review on dye sensitized solar cells (DSSCs): Fundamental concepts and novel materials. Renew. Sustain. Energy Rev. 2012, 16, 5848-5860.

27. Hwang, S.; Lee, H.W.; Park, C.; Lee, H.; Kim, C.; Park, C.; Lee, M.H.; Lee, W.; Park, J.; Kim, K.; et al. A highly efficient organic sensitizer for dye-sensitized solar cells. Chem. Commun. 2007, 46, 4887-4889.

28. King, R.R.; Bhusari, D.; Larrabee, D.; Liu, X.Q.; Rehder, E.; Edmondson, K.; Cotal, H.; Jones, R.K.; Ermer, J.H.; Fetzer, C.M.; et al. Solar cell generations over $40 \%$ efficiency. Prog. Photovolt. Res. Appl. 2012, 20, 801-815.

29. Birkmire, R.W. Compound polycrystalline solar cells: Recent progress and Y2 K perspective. Sol. Energy Mater. Sol. Cells 2001, 65, 17-28.

30. Guter, W.; Schöne, J.; Phillipps, S.P.; Steiner, M.; Siefer, G.; Wekkeli, A.; Welser, E.; Oliva, E.; Bett, A.W.; Dimroth, F. Current-matched triple-junction solar cell reaching $41.1 \%$ conversion efficiency under concentrated sunlight. Appl. Phys. Lett. 2009, doi:10.1063/1.3148341.

31. Concepcion, J.V.; House, R.L.; Papanikolas, J.M.; Meyer, T.J. Chemical approaches to artificial photosynthesis. Proc. Natl. Acad. Sci. USA 2012, 109, 15560-15564. 
32. Osterloh, F. Inorganic Materials as Catalysts for Photochemical Splitting of Water. Chem. Mater. 2008, 20, 35-54.

33. Schwartz, M.O. Cadmium in Zinc Deposits: Economic Geology of a Polluting Element. Int. Geol. Rev. 2000, 42, 445-469.

34. Emsley, J. Nature's Building Blocks: An A-Z Guide to the Elements, 2nd ed.; Oxford University Press Inc.: New York, NY, USA, 2011.

35. Schwarz-Schampera, U.; Herzig, P.M. Indium: Geology, Mineralogy, and Economics; Springer: Heidelberg, Germany, 2002; p. 257.

36. Burton, J.D.; Culkin, F.; Riley, J.P. The abundances of gallium and germanium in terrestrial materials. Geochim. Cosmochim. Acta 1959, 16, 151-180.

37. Moskalyk, R.R. Gallium: The backbone of the electronics industry. Miner. Eng. 2003, 16, 921-929.

38. Greber, J.F. Gallium and Gallium Compounds. In Ullmann's Encyclopaedia of Industrial Chemistry, 6th ed.; John Wiley \& Sons: Hoboken, NY, USA, 2002; p. 30080.

39. Dai, S.; Ren, D.; Li, S. Discovery of the superlarge gallium ore deposit in Jungar, Inner Mongolia, North China. Chin. Sci. Bull. 2006, 51, 2243-2252.

40. Moskalyk, R.R. Review of germanium processing worldwide. Miner. Eng. 2004, 17, 393-402.

41. Höll, R.; Kling, M.; Schroll, E. Metallogenesis of germanium-A review. Ore Geol. Rev. 2007, 30, 145-180.

42. Bernstein, L.R. Germanium geochemistry and mineralogy. Geochim. Cosmochim. Acta 1985, 49, 2409-2422.

43. Fthenakis, V. Life cycle impact analysis of cadmium in CdTe PV production. Renew. Sustain. Energy Rev. 2004, 8, 303-334.

44. Yudovich, Y.E.; Ketris, M.P. Selenium in coal: A review. Int. J. Coal Geol. 2006, 67, 112-126.

45. British Geological Survey. Mineral Profile, Platinum. Available online: http://www.bgs.ac.uk/ mineralsUK/statistics/mineralProfiles.html (accessed on 30 March 2015).

46. Rosa, R.N.; Rosa, D.R.N. Exergy cost of mineral resources. Int. J. Exergy 2008, 5, 532-555.

47. International Lead and Zinc Study Group. Statistics. Available online: http://www.ilzsg.org/static/ statistics.aspx?from=5 (accessed on 15 April 2015).

48. Höök, M.; Hirsch, R.; Aleklett, K. Giant oil field decline rates and their influence on world oil production. Energy Policy 2009, 37, 2262-2272.

49. Höök, M.; Zittel, W.; Schindler, J.; Aleklett, K. Global coal production outlooks based on a logistic model. Fuel 2010, 89, 3546-3558.

50. Hartman, H.L. SME Mining Engineering Handbook, 1st ed.; Society for Mining, Metallurgy \& Exploration Inc.: Ann Arbor, MI, USA, 1992; p. 2394.

51. Safarzadeh, M.S.; Bafghi, M.S.; Moradkhani, D.; Ilkchi, M.O. A review on hydrometallurgical extraction and recovery of cadmium from various resources. Miner. Eng. 2007, 20, 211-220.

52. Alfantazi, A.M.; Moskalyk, R.R. Processing of indium: A review. Miner. Eng. 2003, 16, 687-694.

53. Khan, M.A.; Morris, D.F.C. Application of solvent extraction to the refining of precious metals II. purification of ruthenium. Sep. Sci. Technol. 1967, 2, 635-644.

54. Selenium Tellurium Development Association. Available online: www.stda.org (accessed on 30 March 2015). 
55. Polinares. Fact Sheet: Indium. Polinares Working Paper Nr. 39. Available online: http://www.polinares.eu/ docs/d2-1/polinares_wp2_annex2_factsheet5_v1_10.pdf(accessed on 30 March 2015).

56. USGS. Minerals Yearbook 2012. Germanium [Advance release]. Available online: http://minerals. usgs.gov/minerals/pubs/commodity/germanium/myb1-2012-germa.pdf (accessed on 15 March 2015).

57. Matthey, J. Platinum 2012; Johnson Matthey Public Limited Company: Hertfordshire, UK, 2012; p. 64.

58. Valero, A.L.; Valero, A. A prediction of the exergy loss of the world's mineral reserves in the 21st century. Energy 2011, 36, 1848-1854.

59. Andersson, B.A.; Jacobsson, S. Monitoring and assessing technology choice: The case of solar cells. Energy Policy 2000, 28, 1037-1049.

60. U.S. Department of Energy. Critical Materials Strategy. Available online: http://energy.gov/sites/ prod/files/DOE_CMS2011_FINAL_Full.pdf (accessed on 15 April 2015).

61. International Energy Agency (IEA). PVPS Report: Snapshot of Global PV 1992-2013. Preliminary Trends Information from the IEA PVPS Programme. Available online: http://www.iea-pvps.org/fileadmin/dam/public/report/statistics/PVPS_report_-_A_Snapshot_of_ Global_PV___1992-2013___final_3.pdf (accessed on 30 March 2015).

62. Mikolajczak, C. Availability of Indium and Gallium. Available online: http://www.commodityi ntelligence.com/images/2010/jan/11\%20jan/availability_of_indium_and_galliumwhite_papermik olajczak_sept09.pdf (accessed on 12 May 2015).

63. Elsner, H.; Melcher, F.; Schwarz-Schampera, U.; Buchholz, P. Elektronikmetalle-Zukuenftig steigender Bedarf bei unzureichender Versorgungslage?; Commodity Top News Nr. 33; BGR: Berlin, Germany, 2010.

64. Fthenakis, V. Sustainability metrics for extending thin-film photovoltaics to terawatt levels. MRS Bull. 2012, 37, 1-6.

65. Houari, Y.; Speirs, J.; Candelise, C.; Gross, R. A system dynamics model of tellurium availability for CdTe PV. Prog. Photovolt. Res. Appl. 2014, 22, 129-146.

66. Woodhouse, M.; Goodrich, A.; Margolis, R.; mJames, T.; Dhere, R.; Gessert, T.; Barnes, T.; Albin, D.; Eggert, R. Perspectives on the pathways for cadmium telluride photovoltaic module manufacturers to address expected increases in the price for tellurium. Sol. Energy Mater. Sol. Cells 2013, 115, 199-212.

67. Todorov, T.K.; Reuter, K.B.; Mitzi, D.B. High-Efficiency Solar Cell with Earth-Abundant Liquid-Processed Absorber. Adv. Mater. 2010, 22, E156-E159.

68. Hara, K.; Sato, T.; Katoh, R.; Furube, A.; Yoshihara, T.; Murai, M.; Kurashige, M.; Shinpo, A.; Ito, S.; Suga, S.; et al. Novel Conjugated Organic Dyes for Efficient Dye-Sensitized Solar Cells. Adv. Funct. Mater. 2005, 15, 246-252.

(C) 2015 by the authors; licensee MDPI, Basel, Switzerland. This article is an open access article distributed under the terms and conditions of the Creative Commons Attribution license (http://creativecommons.org/licenses/by/4.0/). 